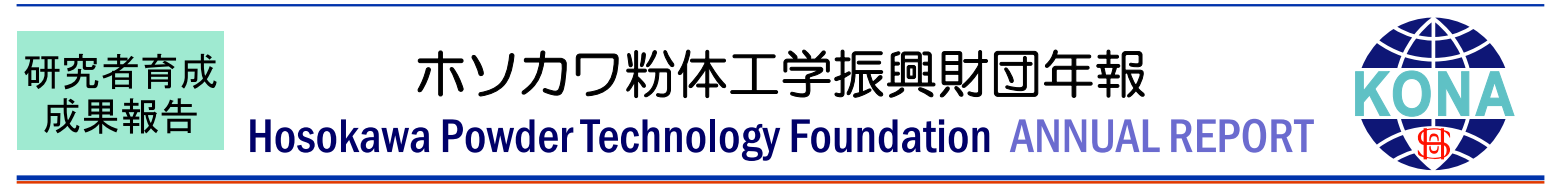

16509

\title{
金ナノ粒子内包中空シリカ粒子のガスセンサーへの応用 \\ Synthesis of Gold Containing Hollow Silica Particles and Its Application to Gas Sensor
}

\author{
援助対象者 Scholarship Student: 中島 佑樹 Yuki NAKASHIMA \\ 名古屋工業大学大学院工学研究科 博士課程後期 2 年 \\ Graduate school of Engineering, Nagoya Institute of Technology University, \\ PhD Student (D2) \\ E-mail: ckz11002@gmail.com
}

\begin{abstract}
研究指導者 Academic Leader：藤 正督 Masayoshi FUJI
教授, Professor

E-mail: fuji@nitech.ac.jp
\end{abstract}

\section{成 果 の 概 要}

中空シリカ粒子とは, 内部の空気層と外部の シリカシェルにより構築される気体/固体コン ポジット粒子である。その特異的な構造から, 高比表面積, 低見かけ密度, 低熱伝導性, 光高 透過性, そして物質内包性・保護性などを有し ている (Fuji M., 2015).

金属粒子は, ナノサイズになると量子サイズ 効果により，バルク体の特性と大きく異なる特 性を示す。金ナノ粒子は，優れた化学特性や光 学特性を有しており，触媒やセンサーとして幅 広く応用されている。しかしながら, ナノ粒子 は表面エネルギーが非常に高いため，容易に凝 集しナノ粒子としての特性が失活してしまうた め，使用環境が限られてしまう。

中空シリカ粒子に金ナノ粒子を内包させるこ とで，金ナノ粒子の凝集失活を抑制し，幅広い 環境下で触媒やセンサーとして応用可能になる と考えられる. Chenらは，高分子粒子内に金
イオンを内包させ，それをテンプレートとして シリカシェルを構築し，焼成することで金ナノ 粒子内包中空シリカ粒子を合成した（Chen J. et al., 2014). 本手法により，均一な金ナノ粒子内 包中空シリカ粒子の合成に成功しているが, 工 程が煩雑であり，高温高圧下での処理が必要で ある。 Duらは, 合成して得られた中空シリカ 粒子に金イオン溶液を導入し中空シリカ粒子内 で金ナノ粒子を合成した（Du X. and He J., 2012). 本手法は, 合成した中空シリカ粒子を 用いるため，工程が簡便であるのが利点である が, 粒子内部での溶液の保持のため, シェル細 孔の精密な制御が要求される.

Yuらは, ポリアクリル酸（PAA）とアンモ ニア水 $\left(\mathrm{NH}_{4} \mathrm{OH}\right)$ の混合水溶液をエ夕ノール 中で中空シリカ粒子のテンプレートとして使用 する手法を報告した（Wan Y. and Yu S.-H., 2008).この手法では, PAAのカルボキシル基 (-COOH) にアンモニアイオン $\left(\mathrm{NH}_{4}^{+}\right)$を作用 させることで, 溶液の極性を増大させている。 
その結果, エタノールに可溶である PAAが不 溶化し中空シリカ粒子のテンプレートとして作 用可能となる，作製されるテンプレートは，高 粘度の液体（ゲル）であるためイオンの内包が 容易に可能である

我々は, ゲルテンプレートの特性に着目し, 金ナノ粒子内包中空シリカ粒子の簡便な合成が $\mathrm{PAA} / \mathrm{NH}_{3}$ エマルジョンテンプレート法を用い ることで可能であると考えた。本研究では，合 成した複合粒子のガスセンサーへの応用を高次 目標として, 金ナノ粒子内包中空シリカ粒子の 簡便な合成手法の確立, および PAA テンプレー 卜を用いて作製される中空シリカ粒子の粒子径 制御を行った。

PAA テンプレートを用いた中空シリカ粒子 の粒子径制御のため, PAA 濃度の検討を行っ た。テンプレート溶液は, テンプレート内の PAA 濃度を 1-24 mM に調整し，アンモニア濃 度を一定とし作製した. $35 \mathrm{ml}$ のエタノール溶 液にテンプレート溶液 $2 \mathrm{ml}$ を添加し, PAAテ ンプレートを作製した. テンプレート作製後, シリカシェルの基となるテトラエチルオルソシ リケート（TEOS）を $2 \mathrm{ml}$ 添加し 6 時間攪拌す ることで, PAAテンプレート上にシリカシェ ルを構築した，得られた粒子をエタノール，お よび水で洗浄することで中空シリカ粒子を作製 した。

各濃度の PAA 溶液を用いて作製された PAA テンプレートの粒度分布を図 1 に示す。各濃度 における平均粒子径は, PAA 濃度の増大にと もなって増大し, $3 \mathrm{mM}$ の時は $26 \mathrm{~nm}, 21 \mathrm{mM}$ の時は $480 \mathrm{~nm}$ であった. 本手法では, エ夕ノー ルに可溶な PAAにアンモニアを作用させるこ とで, PAAの電荷を緩和しエタノール中で PAA を凝集・不溶化して, 中空シリカ粒子の テンプレートとして使用している。本研究にお けるテンプレートの作製条件は，アンモニア濃 度を一定とし, PAA 濃度を可変しているため, PAA に対するアンモニア量はPAA 濃度が低く なるほど増大する。したがって, 低濃度の PAA テンプレートはエタノール中で即座に凝
集・不溶化し，より微細かつ均一になったと考 えられる。一方, 高濃度の PAA テンプレート はエタノール中で即座に凝集・不溶化しないた め, 凝集前にテンプレートが合一し肥大化かつ 多分布となったと考えられる。

各濃度において，作製された中空シリカ粒子 のSTEM写真を図 2 に示す. $3 \mathrm{mM}$ のPAA テ ンプレートを用いて作製された中空シリカ粒子 は, $20 \mathrm{~nm}$ の均一な粒子径を有しており（図 2 (a)), 図 1 の結果で得られた粒子径と類似して いた。したがって, 本手法において PAAの凝 集体が中空シリカ粒子のテンプレートとして使 用されていると考えられる. PAA 濃度の上昇に 対して, 得られる中空シリカ粒子は多分布かつ 肥大になり，15 mM で得られた中空シリカ粒子 は20-150 nmであった（図 2(c))。また, PAA 濃度が $21 \mathrm{mM}$ 以上になると中空シリカ粒子と ともに中実シリカ粒子が観測された (図 $2(\mathrm{~d})$ ). これは, PAA 濃度が上昇することによりアン モニアと相互作用していない PAA 量が増大し, テンプレートがエタノール中に一部可溶になっ たためであると考えられる、テンプレートが可 溶になった結果, 溶解したテンプレート内のア ンモニアがエタノール中で TEOS の触媒として 作用し, 中実シリカ粒子が形成したと考えられ る。以上より, 低濃度の PAA 濃度のテンプレー 卜を用いることで, 均一かつ微細な中空シリカ 粒子が合成可能であることが示された.

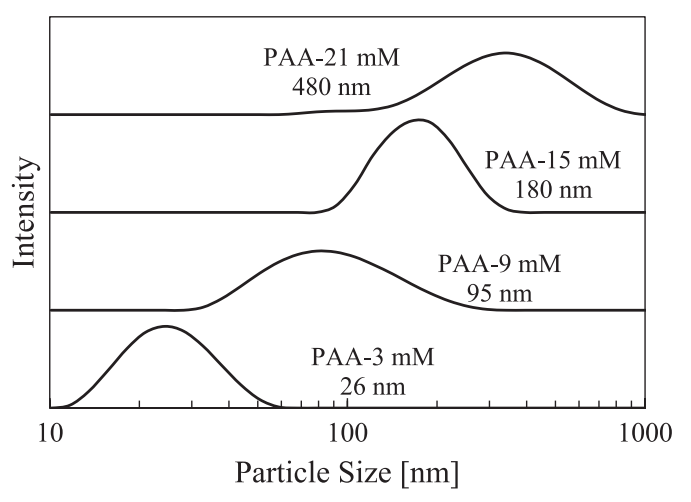

Fig. 1 Particle distribution curves of prepared PAA template using a various PAA concentration solution. 


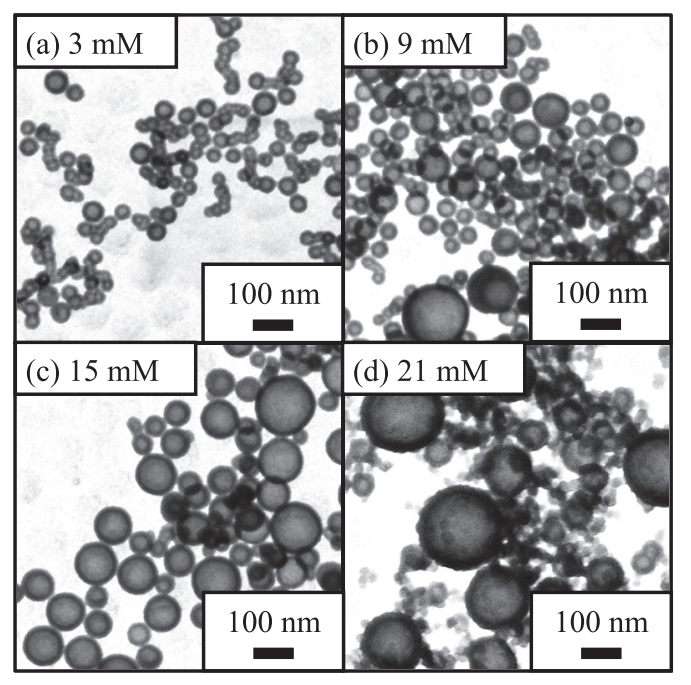

Fig. 2 STEM images of prepared hollow silica nanoparticles using PAA concentration of (a) $3 \mathrm{mM}$, (b) $9 \mathrm{mM}$, (c) $15 \mathrm{mM}$, and (d) $21 \mathrm{mM}$, respectively.

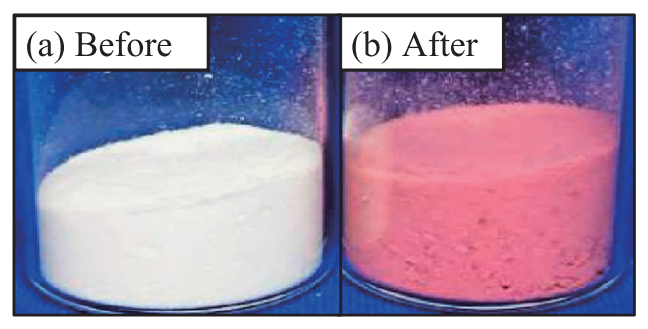

Fig. 3 Photos of prepared gold nanoparticles containing hollow silica nanoparticles (a) before and (b) after calcination.

PAA テンプレートに金の前駆体を混合し中 空シリカ粒子を合成した。得られた中空シリカ 粒子を焼成することで，内部のPAAの除去， および金前駆体を還元し，金ナノ粒子内包中空 シリカ粒子の作製を行った。

得られた粒子の外観写真を図 3 に示す。焼成 前の試料は, 粒子の散乱に起因する白色の外観 であった。一方, 焼成後の試料は, 白赤色の外 観を有していた。金ナノ粒子は，プラズモン共
鳴により，特異的な光の吸収を示す。吸収する 波長は，粒子径に依存し，微細な金ナノ粒子は 赤色の外観を示すことが知られている。した がって, 赤白色は中空シリカ粒子に起因する白 色と金ナノ粒子の赤色が混合して発現した色で あると考えられる。また，凝集した金ナノ粒子 は, プラズモン共鳴を示さないため, 得られた 金ナノ粒子は単一で存在していることが示唆さ れる。したがって，金ナノ粒子がシリカシェル 内に保持されており，形成した金ナノ粒子の凝 集を抑制していると考えられる。

以上より, 低濃度の PAAテンプレートを用 いることで, 均一な中空シリカ粒子の作製が可 能であることが示された。また，金前駆体を PAA テンプレートと混合し，焼成することで 金ナノ粒子内包中空シリカ粒子の簡便な合成手 法が確立できた。

\section{参考文献}

Chen J., Xue Z., Feng S., Tu B., Zhao D., Synthesis of mesoporous silica hollow nanospheres with multiple gold cores and catalytic activity, Journal of Colloid and Interface Science, 429 (2014) 62-67. DOI: 10.1016/j. jcis.2014.05.005

Du X., He J., Carrier effect in the synthesis of rattle-type $\mathrm{Au} @$ hollow silica nanospheres by impregnation and thermal decomposition method, Microporous and Mesoporous Materials, 163 (2012) 201-210. DOI: 10.1016/ j.micromeso.2012.06.045

Fuji M., Hollow particles as controlled small space to functionalize materials, Journal of the Ceramic Society of Japan, 123 (2015) 835-844. DOI: 10.2109/jcersj2.123. 835

Wan Y., Yu S.-H., Polyelectrolyte controlled large-scale synthesis of hollow silica spheres with tunable sizes and wall thicknesses, The Journal of Physical Chemistry C, 112 (2008) 3641-3647. DOI: 10.1021/jp710990b 


\section{外部発表成果}

\section{口頭・ポスター発表}

1. 中島 佑樹, “エマルションテンプレート法 による金ナノ粒子内包中空シリカ粒子の合 成”, 粉体工学会 2017 年度春季研究発表会 (Tokyo, June, 16, 2017).

2. Nakashima Y., "Synthesis of the Gold Containing Hollow Silica Nanoparticles by the Emulsion Template Method", The 7 th Asian Particle Technology Symposium (Taiwan, August, 2, 2017).

3. 中島 佑樹, “エマルションテンプレート法 を用いて作製された中空シリカ粒子形状へ のポリアクリル酸濃度の影響”, 2017 年度 第 2 回 粉体操作に伴う諸現象に関する勉 強会 (Kyoto, August, 8, 2017).

4. 中島 佑樹, “ゲルを用いた中空粒子内部で
の金ナノ粒子形成”, 2017 年度若手研究者 討論会（Gifu, August, 29, 2017).

5. Nakashima Y., "Effect of the PAA Concentration on the Hollow Silica Nanoparticles Prepared by Using the PAA/NH3 Emulsion Template Method", JSPM International Conference on Powder and Powder Metallurgy (Kyoto, November, 6, 2017).

6. 中島 佑樹, “ポリアクリル酸/アンモニアを テンプレートとする金ナノ粒子内包鈴型シ リカ粒子の簡易合成”, 無機マテリアル学会 第 135 回学術講演会 (Kumamoto, November, 16, 2017).

7. Nakashima Y., "Synthesis of Gold Nanopaticles Containing Hollow Silica Nanopaticles by Using Soft Gel as the Template", The 34th International Japan-Korea Seminar on Ceramics Accommodations (Shizuoka, November, 24, 2017). 